\title{
The Effect of Surface Modification with La-M-O (M= Ni, Li) on Electrochemical Performances of $\mathrm{Li}\left[\mathrm{Ni}_{0.8} \mathrm{Co}_{0.15} \mathrm{Al}_{0.05}\right] \mathrm{O}_{2}$ Cathode
}

\author{
Jea Hyeok Ryu, Seuk Buom Kim, and Yong Joon Park’ \\ Department of Atwanced Materials Engineering, Kionggi Lniversitw, Gveonggi $4+3-760$, Korea \\ E-mail: vjpark2006âkonggiack \\ Received November 25, 2008, Accepted Jantury 30, 2009
}

\begin{abstract}
The surface of $\mathrm{Li}\left[\mathrm{Nin}_{8} \mathrm{CO}_{0} \mathrm{~A}_{5} \mathrm{Al}_{0,0} \mathrm{O}_{2}\right.$ cathode particle was modified by lanthanum based oxide to improve electrochemical property and themal stability. The XRD patten of surface layer was indexed with that of LaNiLiO8. The discharge capacity of modified electrode was higher than that of pristine sample, specially at fast charge-discharge rate and high cut-off voltage. In the DSC profile of the charged sample, the generation of heat by exothermic reaction was decreased by surface modification. Such enhancement may by attributed to the presence of stable lanthanum based oxide, which effectively suppressd the reaction between electrode and electrolyte on the surface of $\mathrm{Li}\left[\mathrm{Ni}_{0.8} \mathrm{CO}_{0.15} \mathrm{Al}_{0.05}\right] \mathrm{O}_{2}$ electrode.
\end{abstract}

Key Words: Surface modification, Electrochemical property, Thermal stability. Cathode, Lithium battery

\section{Introduction}

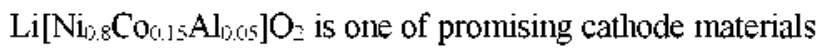
for lithium ion batteries due to its lower cost and higher specific capacity than commercial cathode material such as $\mathrm{LiCOO}_{2}{ }^{1-4}$ However, like most of other cathode materials. it has a some problems such as poor thermal stability, unstable cyclic performance. and insufficient rate capability for commercialization. One of major reasons of these problems is direct contact between the cathode and the electrolyte during charge and discharge process. Actually. LiPF 6 -based electrolyte always contains a small amount of water. which causes breakdown of electrolyte accompanying by $\mathrm{HF}$ generation. ${ }^{5-6}$ The generated HF attacks the surface of cathode material, results in dissolution of transition metal ion and formation of interface layer, which mainly related to a rise in impedance growth and a degradation of lithium ion diffusivity. These surface reactions with electrolyte leads to unstable cyclic performance and insufficient rate capability. Moreover, the generation of heat of cathode at fully charged state is also attributed to the reaction with electrolyte. To overcome these problems and improve the nature of cathode materials. a promising approach is surface modification by coating with stable oxide or phosphate. ${ }^{7.16}$ The coated cathode material can significanly decrease direct contact area with electrolyte. so. reduce the effect of surface reaction between cathode and electrolyte.

In this work, lanthanum based oxide (La-M-O, $\mathrm{M}=\mathrm{Ni}$ and $\mathrm{Li}$ ) was used for surface modification of $\mathrm{Li}\left[\mathrm{Ni}_{1,8} \mathrm{Co}_{0,15} \mathrm{Al}_{(1,15}\right]-$ $\mathrm{O}_{2}$ cathode. Lanthanum based oxide has excellent thermal stability and forms good electrical contact with the metal oxides. which may facilitate electron transfer. ${ }^{17}{ }^{18}$ In particular. it was reported that a doping of rare earth element such as $\mathrm{La} . \mathrm{Ce}$ and $\mathrm{Pr}$ improved discharge capacity and cyclic performance of cathode material. ${ }^{19}$ Herein we fabricated surface modified $\mathrm{Li}\left[\mathrm{Ni}_{3} \mathrm{Co}_{1}: \mathrm{Al}_{1}\right]_{2} \mathrm{O}_{2}$ cathode with lanthanum based oxide and examined the modification effect on electrochemical and thermal property.

\section{Experimental}

Pristine $\mathrm{Li}\left[\mathrm{Ni}_{(1.8} \mathrm{CO}_{0.15} \mathrm{Al}_{(1.15}\right] \mathrm{O}_{2}$ powder was a commercial product of ECOPRO. For surface modification with lanthanum based oxide on the $\mathrm{Li}\left[\mathrm{Ni}_{1,3} \mathrm{CO}_{0.15} \mathrm{Al}_{(1.05}\right] \mathrm{O}_{2}$ powder. $\mathrm{La}\left(\mathrm{NO}_{3}\right)_{3} \cdot 6 \mathrm{H}_{2} \mathrm{O}$ (99.99. Aldrich) was firstly dissolved in the distilled water, followed by continuous stiming for 4 hat $21^{\circ} \mathrm{C}$. Subsequently: $\mathrm{Li}\left[\mathrm{Ni}_{1.1} \mathrm{Co}_{(1.15} \mathrm{Al}_{(1.1)}\right] \mathrm{O}_{2}$ was added to the prepared solution and mixed thoroughly for $2 \mathrm{~h}$ at $80^{\circ} \mathrm{C}$. The slurry was dried in an oven at $100{ }^{\circ} \mathrm{C}$ for $12 \mathrm{~h}$ and heat-treated in a furnace at $700{ }^{\circ} \mathrm{C}$ for $5 \mathrm{~h}$. The estimated concentration of lanthanum based oxide(assumed as $\mathrm{La}_{5} \mathrm{O}_{3}$ in the experimental step) in the $\mathrm{Li}\left[\mathrm{Ni}_{(1.3} \mathrm{Co}_{0.15} \mathrm{Al}_{1.05}\right] \mathrm{O}_{2}$ powders was varied from 1.0 to $3.0 \mathrm{wt} \%$. X-ray diffraction (XRD) patterns of powders were obtained using a Philips $\mathrm{X}$-ray diffractometer in the $2 \mathrm{q}$ range of $15^{\circ}$ to $70^{\circ}$ with monochromatized $\mathrm{Cu}-K_{\alpha}$ madiation $(\lambda=1.5406$ $\AA$ ). The microstructure of the powder was observed using a FESEM (fieldenission scanning electron microscopy. JEOLJSM 6500F).

For electrochemical testing cathode slurry was prepared by mixing the oxide powder, carbon black (Super P). and poly (viny lidene)fluoride (PVDF) in a weight ratio of 80:12:8. After $24 \mathrm{hr}$ of ball mill processing, the viscous slurry was coated onto aluminum foil using a Dr. blade then. dried at $90^{\circ} \mathrm{C}$ in an oven. The coin-type cell (2032 size) consists of a cathode, a Li metal anode, a separator, and an electrolyte. The electrolyte was $1 \mathrm{M} \mathrm{LiPF}_{6}$ with ethylene carbonate/dimethyl carbonate (EC/DMC) $(1: 1 \mathrm{vol} \%)$. Cells were subjected to galvanostatic cycling using a WonAtech șystem in the voltage range of $4.3 \sim 3.0 \mathrm{~V}$ or $4.8 \sim 2.0 \mathrm{~V}$ at various charge-discharge rates between $0.5-6 \mathrm{C}$. DSC (differential scanning calorimeter) samples for the cathode were prepared by following treatment before test. The cells containing sample electrode was charged to $4.3 \mathrm{~V}$ at the current density of $40 \mathrm{~mA} / \mathrm{g}$. and it was held at that potential until the current density reached to 4 $\mathrm{mA} / \mathrm{g}$. Then these cells were disassembled in a dry room to remove the charged positive electrode $4.5 \mathrm{mg}$ of the positive electrode and $3 \mu \mathrm{L}$ of fresh electrolyte were sealed in a high 
pressure DSC pan. The heating rate and temperature range of the DSC tests were $5^{\circ} \mathrm{C} / \mathrm{min}$ and $25-300^{\circ} \mathrm{C}$. respectively.

\section{Results and Discussion}

The Phase of $\mathrm{Li}\left[\mathrm{Ni}_{8} \mathrm{CO} \mathrm{C}_{5} \mathrm{Al}_{\mathrm{i}}\right] \mathrm{O}_{2}$ powder was investigated by XRD analysis as shown in Fig. 1. The XRD patterns of $\mathrm{Li}\left[\mathrm{Ni}_{1,8} \mathrm{CO}_{0,15} \mathrm{Al}_{1,0,15}\right] \mathrm{O}_{2}$ could be indexed to the typical layered stnicture with $R \overline{3} m$ space group. Main reflection peaks of surface modified samples were identical to those of pristine sample. However. small diffraction peaks were detected at $2 \theta=24^{\circ} \sim 34^{\circ}$ (marked with arrow). The detailed XRD pattern in the $2 \theta=24^{\circ}-36^{\circ}$ range was displayed in Fig. 2a. No diffraction peak was detected in the XRD pattern of pristine $\mathrm{Li}\left[\mathrm{Ni}_{1,8} \mathrm{Co}_{0,15} \mathrm{Al}_{1,03}\right] \mathrm{O}_{2}$ powder. But. the surface modified samples showed small peaks in that range and the intensity of peaks was increased as the increase of $\mathrm{La}$ content. which indicats that the peaks is associated with surface film layer of La-M-O. Accoding to the JCPDS data. the small peaks can be indexed with the diffraction pattern of $\mathrm{La}_{4} \mathrm{NiLiO}_{8}$ (Fig. 2b). In the experimental step, it was expected that the surface would be coated by $\mathrm{La}_{2} \mathrm{O}_{3}$. however the $\mathrm{La}$ source was reacted with $\mathrm{Ni}$ and $\mathrm{Li}$ on the surface of pristine powder. $\mathrm{La}_{4} \mathrm{NiLiO}_{8}$ was practically formed as a coating layer. However, it is possible that a small amount of composite type particle was formed on the surface of the pristine powder.

Figure 3 shows the scanning electron microscopy (SEM) images of surface of the pristine and modified $\mathrm{Li}\left[\mathrm{Ni}, \mathrm{CO}_{0}\right] 5^{-}$ $\left.\mathrm{Al}_{(1 \mathrm{C})}\right] \mathrm{O}_{2}$ powder. The size of pristine powder was $5 \sim 8 \mu \mathrm{m}$. A particle was composed of smooth-edged $0.1-0.5 \mu \mathrm{m}$ sized primary particles (Fig. 3a). At high magnification (X 30000) (Fig. 3b-e). the surface morphologies of coated particles were distinctly different from those of pristine one. The film layer, expected as $\mathrm{La}_{4} \mathrm{NiLiO}_{8}$ coating layer was distinctly observed on the surface of modified $\mathrm{Li}\left[\mathrm{Ni}_{8} \mathrm{CO}_{15} \mathrm{Al}_{15}\right] \mathrm{O}_{2}$ powder. In contrast the surface of pristine sample was clear and no film layer was observed. It is not clear that the uniform coating film was formed on the surface. However accoding to the Martin et $a l^{20}$. many of coating particles adhere to the surfaces of the pristine powder, instead of homogeneous coating film, could enhance electrochemical properties of the cathode material.

To investigate the surface modification effect on capacity, cyclic performance and rate capability the electrochemical property of pristine and surface modified $\mathrm{Li}\left[\mathrm{Ni}_{(1.8} \mathrm{Co}_{(1,15} \mathrm{Al}_{1,0.5}\right]$ $\mathrm{O}_{2}$ electrode was characterized. Figure ta exhibits the initial voltage profile of the pristine and surface modified samples at a rate of $0.5 \mathrm{C}$ between 3 and $4.3 \mathrm{~V}$ ( $1 \mathrm{C}$ rate was set as 180 $\mathrm{mA} / \mathrm{g}$ ). The 1 and $2 \mathrm{wt} \%$ surface modified sample displays a little higher $(5-7 \%)$ discharge capacity than the pristine sample. Theoretically. the surface modified sample should have lower discharge capacity because of additive of coating material, which does not participate in lithium intercalationdeintercalation process. However the discharge capacity we measure is the value which is hindered from the surface unwanted-reaction between electrode and electrolyte. The stable surface coating laver can protect the electrode from the reaction with electroly te by preventing from direct contact, so it may facilitate lithium diffusion and increase discharge

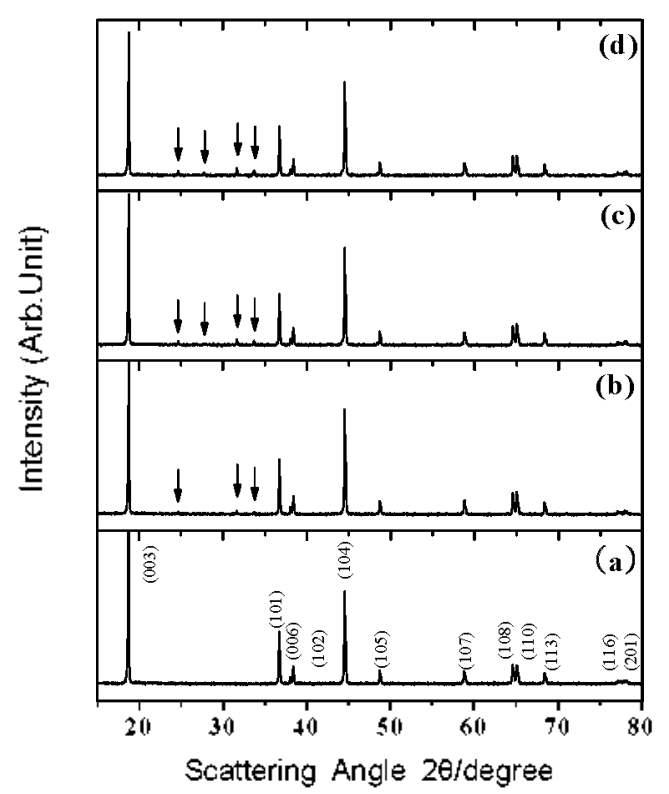

Figure 1. XRD pattems of $\mathrm{Li}\left[\mathrm{Ni}_{0.3} \mathrm{C}_{0.13} \mathrm{Al}_{0.05}\right] \mathrm{O}_{2}$ powder. (a) pristine sample: (b) surface modified sample with 1 wt\% La-M-O; (c) surface modified sample with 2 wt\% La-M-O. (d) surface modified sample with 3 wt $\%$ La-M-O.
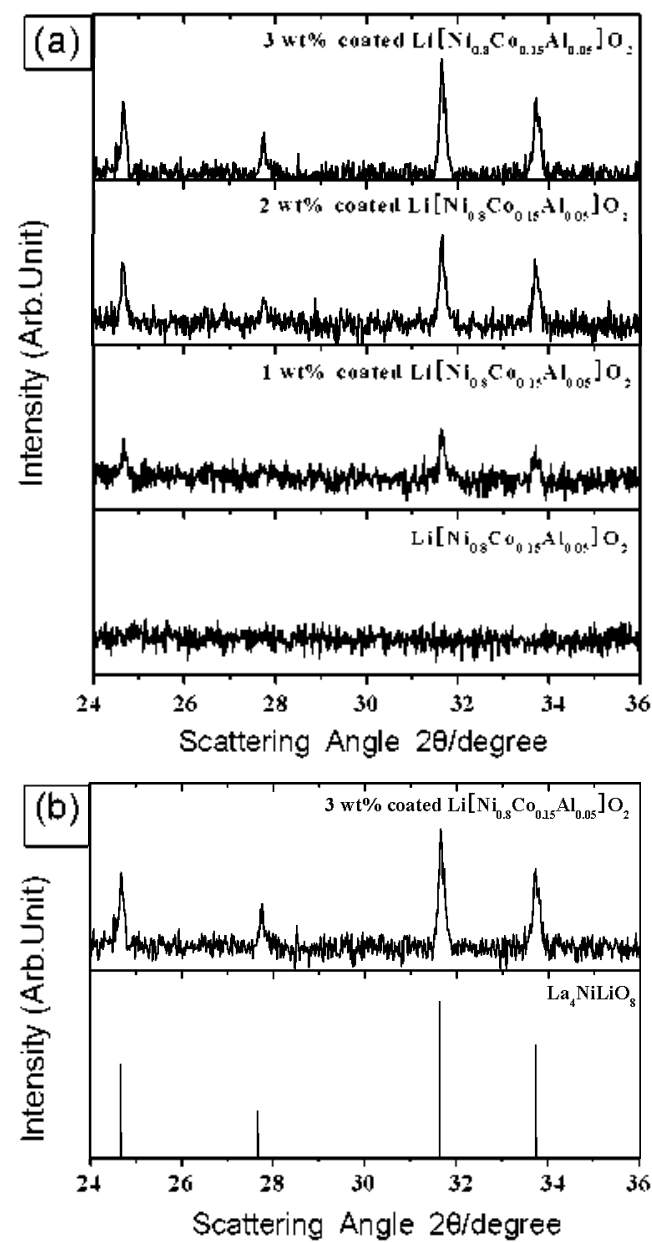

Figure 2. (a) The detailed XRD pattern of pristine and surface modified $\mathrm{Li}\left[\mathrm{Ni}_{0.8} \mathrm{Co}_{0.13} \mathrm{Al}_{0.05}\right] \mathrm{O}_{2}$ powder in the $2 \theta=24^{\circ} \sim 36^{\circ}$ range: (b) Comparison of XRD pattern between surface modified sample with 3 wt $\% \mathrm{La}-\mathrm{M}-\mathrm{O}$ and $\mathrm{L} a_{4} \mathrm{NiLiO}$. 

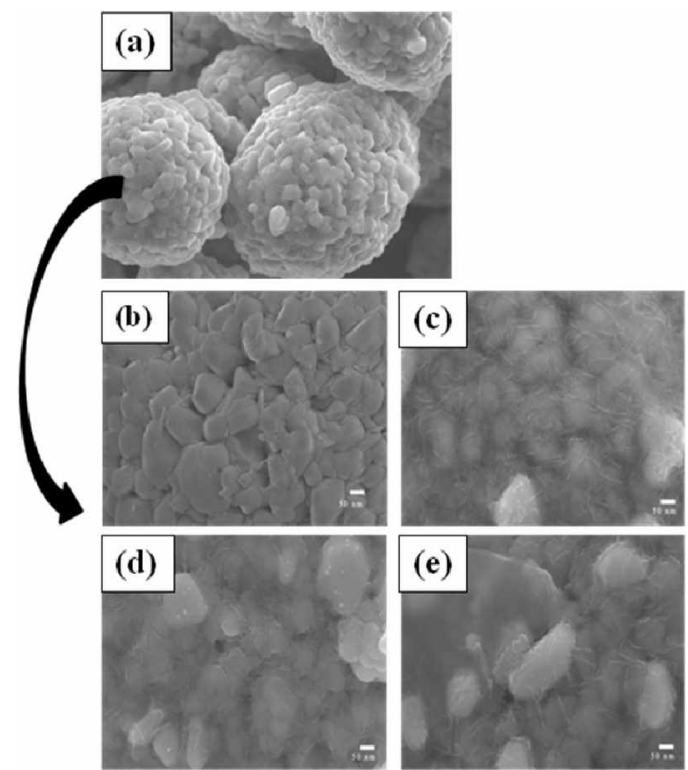

Figure 3. Scanming electron microscopy (SEM) mages of $\mathrm{L}_{1}\left[\mathrm{~N}_{10.8}\right.$ $\left.\mathrm{Co}_{0.15} \mathrm{Al}_{0.05}\right] \mathrm{O}_{2}$ powder. (a) powder shape of pristine sample ( $\mathrm{X}$ 5000): (b) surface morphology of pristine sample (X 30,000); (c) surface morphology of surface modified sample with $1 \mathrm{wt} \% \mathrm{La}-\mathrm{M}-\mathrm{O}$ (X 30,000$)$; (d) surface morphology of surface modified sample with 2 wt\% La-M-O (X 30,000) (e) surface morphology of surface modified sample with 3 wt\% La-M-O 3 wt\% La-M-O (X 30,000).
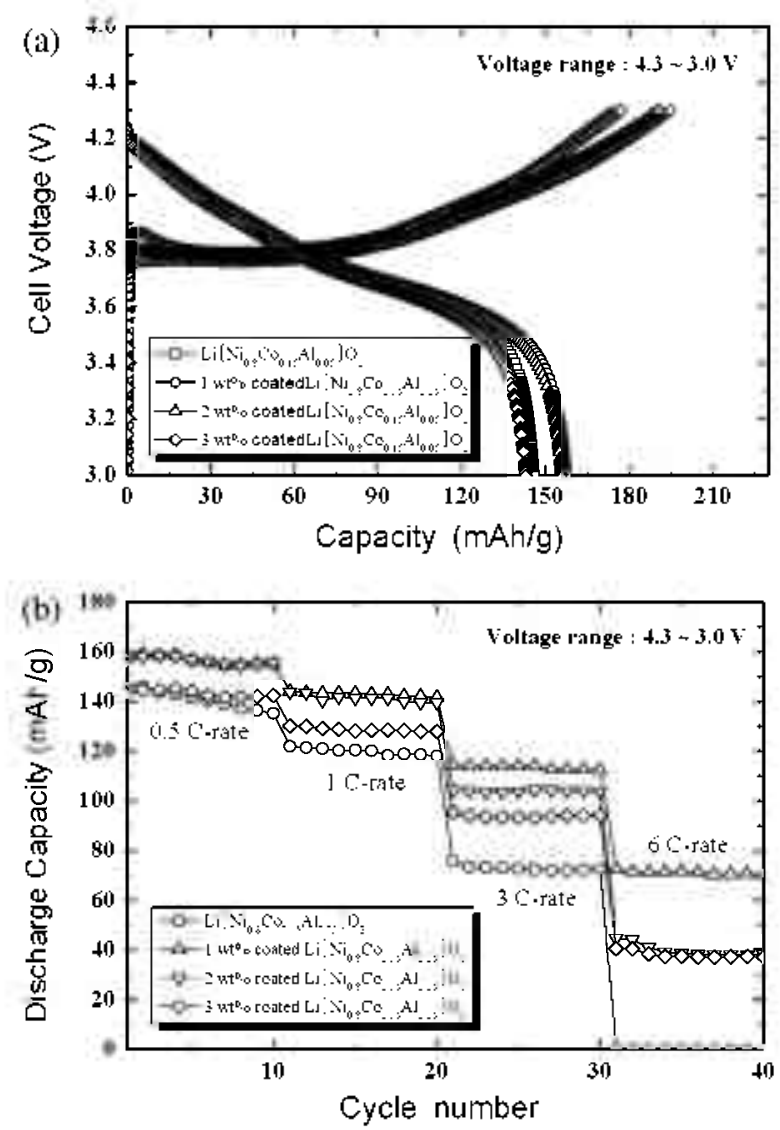

Figure 4. (a) Initial charge-discharge profiles of pristine and surface modified $\mathrm{Li}\left[\mathrm{Ni}_{1,} \mathrm{CO}_{0}: \mathrm{Al}_{0}\right.$; $] \mathrm{O}_{2}$ electrode in the voltage range of $4.3 \sim 3.0 \mathrm{~V}$ at $0.5 \mathrm{C}$ rate: (b) Discharge capacity and cyclic performances of pristine and surface modified $\mathrm{Li}\left[\mathrm{Ni}_{0.8} \mathrm{C}_{0.15} \mathrm{Al}_{0.05}\right] \mathrm{O}_{2}$ electrode in the voltage range of $4.3-3.0 \mathrm{~V}$ at $0.5,1,3$ and $6 \mathrm{C}$ rate.
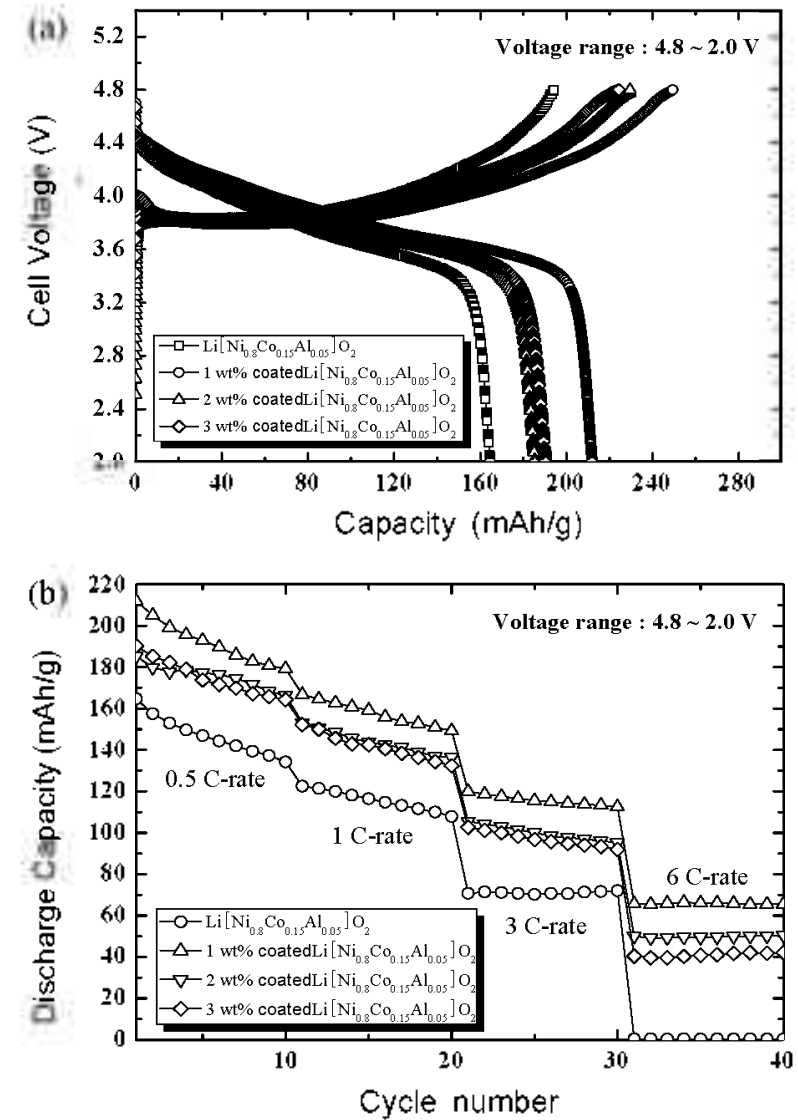

Figure 5. (a) Initial charge-discharge profiles of pristine and surfáce modified $\mathrm{Li}\left[\mathrm{Ni}_{0} \mathrm{CO}_{014} \mathrm{Al}_{\left.l_{1 / 1}\right]} \mathrm{O}_{3}\right.$ electrode in the voltage range of $4.8 \sim 2.0 \mathrm{~V}$ at $0.5 \mathrm{C}$ rate; (b) Discharge capacity and cyclic pertormances of pristine and surface modified $\mathrm{Li}\left[\mathrm{Ni}_{0.8} \mathrm{C}_{0.15} \mathrm{Al}_{0.05}\right] \mathrm{O}_{2}$ electrode in the voltage range of $4.8-2.0 \mathrm{~V}$ at $0.5,1,3$ and $6 \mathrm{C}$ rate.

capacity. Similar capacity enhancement by surface modification was reported by previous works. ${ }^{13.21-223}$

The discharge capacity of $3 \mathrm{wt} \%$ surface modified sample was smaller than that of 1 and $2 \mathrm{wt} \%$ surface modified sample. Thick La-M-O surface layer may act as obstacle of lithium diffusion and electron conduction. so the increase of thickness of surface layer could deteriorate discharge capacity. Figure tb presents the discharge capacity of $\mathrm{Li}\left[\mathrm{Ni}_{0.8} \mathrm{CO}_{0.15} \mathrm{Al}_{0.15}\right] \mathrm{O}_{2}$ electrode before and after modification at each selected $\mathrm{C}$ rate. As mentioned, coated sample showed similar or a little enhanced discharge capacity at $0.5 \mathrm{C}$ rate. With the increase of $\mathrm{C}$ rate. the capacity difference between pristine and surface modified sample was more prominent. The surface modified sample delivered superior discharge capacity to the pristine sample.

The effect of La-M-O surface layer on electrochemical property was more prominently observed at a high cut-off voltage. The Figure 5a shows the initial charge-discharge profile of pristine and coated $\mathrm{Li}\left[\mathrm{Ni}_{1.8} \mathrm{CO}_{0.15} \mathrm{Al}_{1,5.5}\right] \mathrm{O}_{2}$ electrode at a rate of $0.5 \mathrm{C}$ betwee 2 and $4.8 \mathrm{~V}(1 \mathrm{C}$ rate was set as 180 $\mathrm{mA} / \mathrm{g}$ ). The surface modified sample presented higher discharge capacity than the pristine one more distinctly. The discharge capacity of $1 \mathrm{wt} \%$ coated electrode was $210 \mathrm{mAh} / \mathrm{g}$. which is about $25 \%$ higher than that of pristine sample. As shown in Fig. $5 \mathrm{~b}$, the rate capability was also enhanced by surface modification. As the increase of cut off voltage. the reaction 


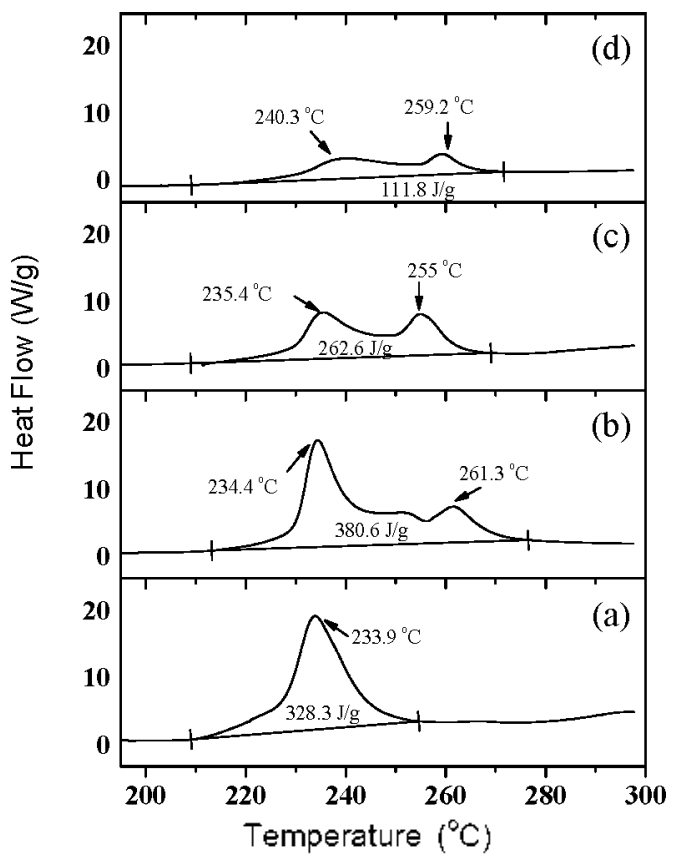

Figure 6. DSC scans of pristine and surface modified $\mathrm{Li}\left[\mathrm{Ni}_{0.8} \mathrm{Co}_{0.15}-\right.$ $\left.\mathrm{Al}_{0.05}\right] \mathrm{O}_{2}$ electrode at fully charged state (cut off woltage was $4.3 \mathrm{~V}$ ). (a) pristine sample: (b) surface modified sample with $1 \mathrm{wt} \% \mathrm{La}-\mathrm{M}-\mathrm{O}$, (c) surface modified sample with 2 wt\% La-M-O; (d) surface modified sample with 3 wt\% La-M-O.

between surface of electrode and electroly te will grow. which make the surface of cathode material more vulunable. The vulunable surface of electrode could be protected by surface coating layer. The stable surface film layer could reduce transition metal dissolution ${ }^{2-1}$ and prevent $\mathrm{HF}$ attack originated from decomposition of electrolyte..$^{35.76}$

As a following test. thermal stability of the $\mathrm{Li}\left[\mathrm{Ni}_{3,8} \mathrm{CO}_{0,15-}\right.$ $\mathrm{Al}_{10} \mathrm{O}_{2}$ electrode before and after surface modification was investigated using DSC analysis. The electrodes were charged to $4.3 \mathrm{~V}$ before the test and sealed with fresh electrolyte in a high pressure DSC pan. Figure 6 shows the DSC profile of pristine and surface modified $\mathrm{Li}\left[\mathrm{Ni}_{1.8} \mathrm{Co}_{0115} \mathrm{Al}_{1016}\right] \mathrm{O}_{2}$ electrode. For pristine sample, thermal reaction with the electrolyte commenced at roughly $\sim 210^{\circ} \mathrm{C}$ and heat was generated until $-255^{\circ} \mathrm{C}$. A large exothermic peak was located at $\sim 234^{\circ} \mathrm{C}$. The DSC profile of surface modified sample displayed a slightly different shape. The intensity of large exothermic peak was decreased as the increase of coating content. However. a new exothermic peak was created between $255 \sim 261{ }^{\circ} \mathrm{C}$. Even though considering the new exothermic peak, thermal stability of the electrode was prominently enhanced by 2 and $3 \mathrm{wt} \%$ surface modification. The generation of heat of $3 \mathrm{wt} \%$ surface modified electrode was just $111.8 \mathrm{~J} / \mathrm{g}$. which is about $34 \%$ of that of pristine electrode. Although $1 \mathrm{wt} \%$ surface modified sample generated a little larger heat than the pristine one. the heat generation from $1^{\text {st }}$ peak was decreased and the $2^{\text {nd }}$ peak was located at higher temperature range, which can analyze a little superior thermal stability.

\section{Conclusions}

The effects of surface modification with lanthanum based oxide on electrochemical and thernal property of $\mathrm{Li}[\mathrm{Ni}$ $\mathrm{CO}_{0.15} \mathrm{Al}_{\text {..15 }} \mathrm{O}_{2}$ were investigated. The lanthanum source was reacted with $\mathrm{Ni}$ and $\mathrm{Li}$ on the surface of $\mathrm{Li}\left[\mathrm{Ni}_{1,3} \mathrm{Co}_{(1.15} \mathrm{Al}_{1,05}\right] \mathrm{O}_{2}$ powder. $\mathrm{La}_{4} \mathrm{NiLiO}_{4}$ was practically formed as a surface layer. The surface modified electrode showed superior discharge capacity to that of pristine sample, specially at high $\mathrm{C}$ rate. The effect of surface modification on electrochemical property was more prominently observed at a high cut-off voltage. Thermal stability of $\mathrm{Li}\left[\mathrm{Ni}_{1} \& \mathrm{CO}_{15} \mathrm{Al}_{10}\right]_{2}$ also enhanced by surface modification with lanthanum based oxide. which could be ascribed to the successful suppression of surface reaction between electrode and electrolyte by stable lanthanum based oxide layer.

Acknowledgments. The work was carried out with financial support from the 2007 Kyonggi-University specialization program.

\section{References}

1. Kim, H.-B.: Park, B.-C.; Myung, S.-T.; Amine, K.; Prakash, I.; Sun, Y.-K. J. Power Sources 2008, 179, 347 .

2. Bellaroulak, I.: Lu, W.; Lill, I.; Vissers, D.; Amine, K. J. Power Sources 2007, 174, 905 .

3. Wang, Y.; Tiang, J.; Dahn, T. R. Electrochent Conmm 2007, 9, 2534.

4. Park, Y. J.: Lee, J. W.: Lee, Y.-G.: Kim, K. M.: Kang, M. G.; Lee, Y. Bull. Korean Chem. Soc. 2007, 28, 2226.

5. Edstrom, K: Gustafsson, T.; Thomas, J. O. Electrochim. Acta 2004, 50, 379.

6. Myung, S.-T.; Izumi, K.: Komaba, S.; Sun, Y.-K.: Yáshiro, $\mathrm{H}$.; Kumagai, N. Chem. Hater: 2005, 17, 3695.

7. Ryu, K. S.; Lee, S. H.; Park, Y. J. Bull. Korean Chent. Soc. 2008. $29,1737$.

8. Son, J-T. Bull. Korean Chem. Soc. 2008, 29, 1695

9. Cho, T.: Lee, T-G.; Kim, B.; Park, B. Chem . Later. 2003. 15. 3190.

10. Cho, J; Kim, Y. I.; Park, B. J. Electrochent. Soc 2001, 148, Al 110.

11. Zhang, Z. R.; Liu, H. S.; Gong, Z. L.; Yang, Y. J. Electrochem. Soc. 2004, 151, A599

12. Cho, J. Electrochem. Commu 2003, $5,146$.

13. Kim, G.-Y.: Park, Y, J.: Jung, K. H.: Yang, D.-I.: Lee, J. W: Kim, H.-G. J. Appl Electrochen. 2008, 38, 1477.

14. Cho, J.; Kim, H.; Park, B. J. Electrochent. Soc. 2004, 151, Al707.

15. Amine, K.; Yasuda, H.: Yamachi, M. Electrochem. Solid State Letr. 2000, 3, 178

16. Rru, K. S.; Lee, S. H.; Koo, B. K.; Lee, J. W.; Kim, K. M:; Park, Y. J. J. Appl. Electrochem. 2008, $38,1385$.

17. Fey, G. T.: Muralidharan, P.; Lu, C.-Z: Cho, Y. D. Electrochim. Acta $2006,51,4850$.

18. Fey, G. T.; Muralidharan, P.; Lu, C.-Z; Cho, Y. D. Solid State Ionics 2005, $176,2759$.

19. Ding, Y; Zhang, P, Jiang, Y.; Gao, D. Solid State Ionics 2007, 178,967

20. Kim, Y.: Kim, H. S.; Martin, S. W. Electrochim. Acta 2006, 52 , 1316.

21. Lee, H.; Kim, M. G.; Cho, J. Electrochem. Conmu. 2007, 9, 149.

22. Wu, Y, Manthiram, A. Electrochem. Solid State Left. 2006, 9, A221.

23. Cho, T; Kim, T. T; Kim, J.; Noh, M.; Park, B. J. Electrochem. Soc: 2004, 151, A 1899.

24. Noh, M.: Lee, Y.; Cho J. J. Electrochem. Soc. 2006, 153, A935

25. Thackeray, M. M.; Johnson, C. S.; Kim, I. S.: Lanzze, K. C.; Vaughey, I. T.; Dietz, N.; Abraham, D.; Hackney, S. A.; Zeltner, W.; Anderson, M. A. Electrochent Common. 2003, $5,752$.

26. Myung, S.-T; Izumi, K, Komaba, S; Yashiro, H.; Bang, H. T.; Sun, Y. K.; Kumagai, N. J. Phys. Chem. C 2007, 111, 4061. 